\title{
A Legacy of Low-Impact Logging does not Elevate Prevalence of Potentially Pathogenic Protozoa in Free-Ranging Gorillas and Chimpanzees in the Republic of Congo: Logging and Parasitism in African Apes
}

\author{
Thomas R. Gillespie, ${ }^{1,2,8}$ David Morgan, ${ }^{3,4}$ J. Charlie Deutsch, ${ }^{5}$ Mark S. Kuhlenschmidt, ${ }^{5}$ \\ Johanna S. Salzer, ${ }^{1}$ Kenneth Cameron, ${ }^{6}$ Trish Reed, ${ }^{6}$ and Crickette Sanz ${ }^{7}$ \\ ${ }^{1}$ Department of Environmental Studies and Program in Population Biology, Ecology, and Evolution, Emory University, Atlanta, GA \\ ${ }^{2}$ Department of Environmental and Occupational Health, Rollins School of Public Health, Emory University, Atlanta, GA \\ ${ }^{3}$ Fisher Center for the Study and Conservation of Apes, Lincoln Park Zoo, Chicago, IL \\ ${ }^{4}$ Congo Program, Wildife Conservation Society, Brazzaville, Republic of Congo \\ ${ }^{5}$ Department of Pathobiology, College of Veterinary Medicine, University of Illinois, Urbana, IL \\ ${ }^{6}$ Global Health Program, Wildlife Conservation Society, Bronx, NY \\ ${ }^{7}$ Max Planck Institute for Evolutionary Anthropology, Leipzig, Germany \\ ${ }^{8}$ E510 Math and Science Center, Emory University, 400 Dowman Drive, Atlanta, GA 30322
}

\begin{abstract}
Many studies have examined the long-term effects of selective logging on the abundance and diversity of free-ranging primates. Logging is known to reduce the abundance of some primate species through associated hunting and the loss of food trees for frugivores; however, the potential role of pathogens in such primate population declines is largely unexplored. Selective logging results in a suite of alterations in host ecology and forest structure that may alter pathogen dynamics in resident wildlife populations. In addition, environmental pollution with human fecal material may present a risk for wildlife infections with zoonotic protozoa, such as Cryptosporidium and Giardia. To better understand this interplay, we compared patterns of infection with these potentially pathogenic protozoa in sympatric western lowland gorillas (Gorilla gorilla gorilla) and chimpanzees (Pan troglodytes troglodytes) in the undisturbed Goualougo Triangle of NouabaléNdoki National Park and the adjacent previously logged Kabo Concession in northern Republic of Congo. No Cryptosporidium infections were detected in any of the apes examined and prevalence of infection with Giardia was low (3.73\% overall) and did not differ between logged and undisturbed forest for chimpanzees or gorillas. These results provide a baseline for prevalence of these protozoa in forest-dwelling African apes and suggest that low-intensity logging may not result in long-term elevated prevalence of potentially pathogenic protozoa.
\end{abstract}

Keywords: Cryptosporidium, disease ecology, disturbance ecology, Giardia, zoonoses

\section{INTRODUCTION}

Published online: March 18, 2010

Correspondence to: Thomas R. Gillespie, e-mail: thomas.gillespie@emory.edu
Selective logging is the dominant commercial activity in forested areas of the tropics with strong conservation potential (Frumhoff, 1995; Struhsaker, 1997). This potential 
is arguably strongest in central Africa, where a combination of weak communications and infrastructure, lack of logistics systems, and high transportation costs result in highly selective timber extraction, focusing on a few economically valuable species occurring at low densities (Boardman et al., 2007; Clark et al., 2009).

During the last decade, the timber industry has thrived in central Africa and many of the remaining forests have been allocated to timber concessions. With extraction rates of 1-4 trees harvested per hectare, damage to remaining forest is relatively limited and disrupts only $7-20 \%$ of the canopy (Hall et al., 2003; Van Gemerden, 2003). This is compared to extraction rates of 5-10 trees per hectare and associated disruption of $25-50 \%$ of the canopy typical of other forested regions of the tropics (Skorupa, 1987; Chapman et al., 2000). Whereas some species of wildlife thrive in such low-intensity operations, even low-level extraction appears to have a negative effect on some primate species, including chimpanzees (White, 1992; Barnes and Lahm, 1997; White and Tutin, 2001; Matthews, 2004).

Although logging is known to reduce the abundance of some primate species due to associated hunting and the loss of food sources for frugivores (Wilkie and Carpenter, 1998; Chapman et al., 2000), the potential role of parasite infections in such primate population declines remains largely unexplored. Logging results in a suite of alterations in host ecology forest structure and human-wildlife overlap that may alter infection prevalence and infection risk in resident populations. Patterns of parasitism in wildlife populations are influenced by host ranging patterns, density, intraspecific and interspecific contact rates, diet, and immune function (Hudson et al., 2001; Nunn et al., 2003; Gillespie et al., 2005, 2008; Beldomenico et al., 2008). Studies on a variety of species have demonstrated that these characteristics can be affected by changes in forest structure (Olupot et al., 1994; Heydon and Bulloh, 1997; Patriquin and Barclay, 2003).

Giardia and Cryptosporidium are protozoal pathogens that infect humans, domestic animals, and wildlife worldwide (Appelbee et al., 2005). In humans and livestock, these parasites cause diarrhea and other enteric disorders that can contribute to nutritional deficiencies and impaired weight gain (Savioli et al., 2006; Thompson, 2004). Little information exists about the clinical affects of these parasites on their wildlife hosts; however, environmental pollution with human fecal material is recognized as a potential pathogen pathway for wildlife infections with zoonotic protozoal parasites, such as Giardia and Cryptos- poridium (Appelbee et al., 2005). Considering the capacity of such infections to put wildlife populations at risk, it is important to monitor the health status of wildlife in general and endangered species in particular. It is equally important to identify potential pathogen transmission pathways from humans and domestic animals to wildlife.

To better understand the affect of selective logging on the transmission and persistence of these protozoal pathogens, we examined noninvasively collected fecal samples from 134 sympatric western lowland gorillas (Gorilla gorilla gorilla) and chimpanzees (Pan troglodytes troglodytes) in the northern Republic of Congo. We compared patterns of infection between ape samples from the Kabo Logging Concession with those sampled from the adjoining undisturbed forest of the Nouabalé-Ndoki National Park.

\section{Methods}

\section{Study Site}

The Sangha River Tri-National Conservation Area $\left(36,236 \mathrm{~km}^{2}\right)$ is notable for its extensive tracks of forest and transboundary protected area network: Nouabalé-Ndoki National Park in Republic of Congo, Lobéké National Park in Cameroon, and Dzanga-Ndoki National Park and Dzanga-Sangha Special Reserve in Central African Republic (Fig. 1). This region is largely unpopulated with human densities estimated at 0.7 to 0.8 people per $\mathrm{km}^{2}$ (Auzel and Wilkie, 2000). Semi-nomadic Ba'Aka pygmies and Bantu agriculturalist-fishermen live in complex, interdependent economic and social relationships (Eves and Ruggiero, 2000). Most villages are along major waterways leaving the remote interior forest with little human development and associated pressures. However, commercial logging is rapidly expanding along the periphery of the Tri-National Conservation Area. Timber exploitation in these remote areas is relatively labor-intensive and can result in the transient relocation of skilled workers and their families, introducing the risk of novel opportunities for pathogen transmission from people to resident wildlife.

The Kabo Logging Concession $\left(2800 \mathrm{~km}^{2}\right)$, operated by the Congolaise Industrielle des Bois, has been logged to varying degrees for the past 40 years. The pristine forests of the adjoining Goualougo Triangle $\left(310 \mathrm{~km}^{2}\right)$ were initially part of the Kabo Concession until biological surveys by the Wildlife Conservation Society revealed the conservation significance of this region's great ape populations and their habitat. In June 2003, the Congolese government 


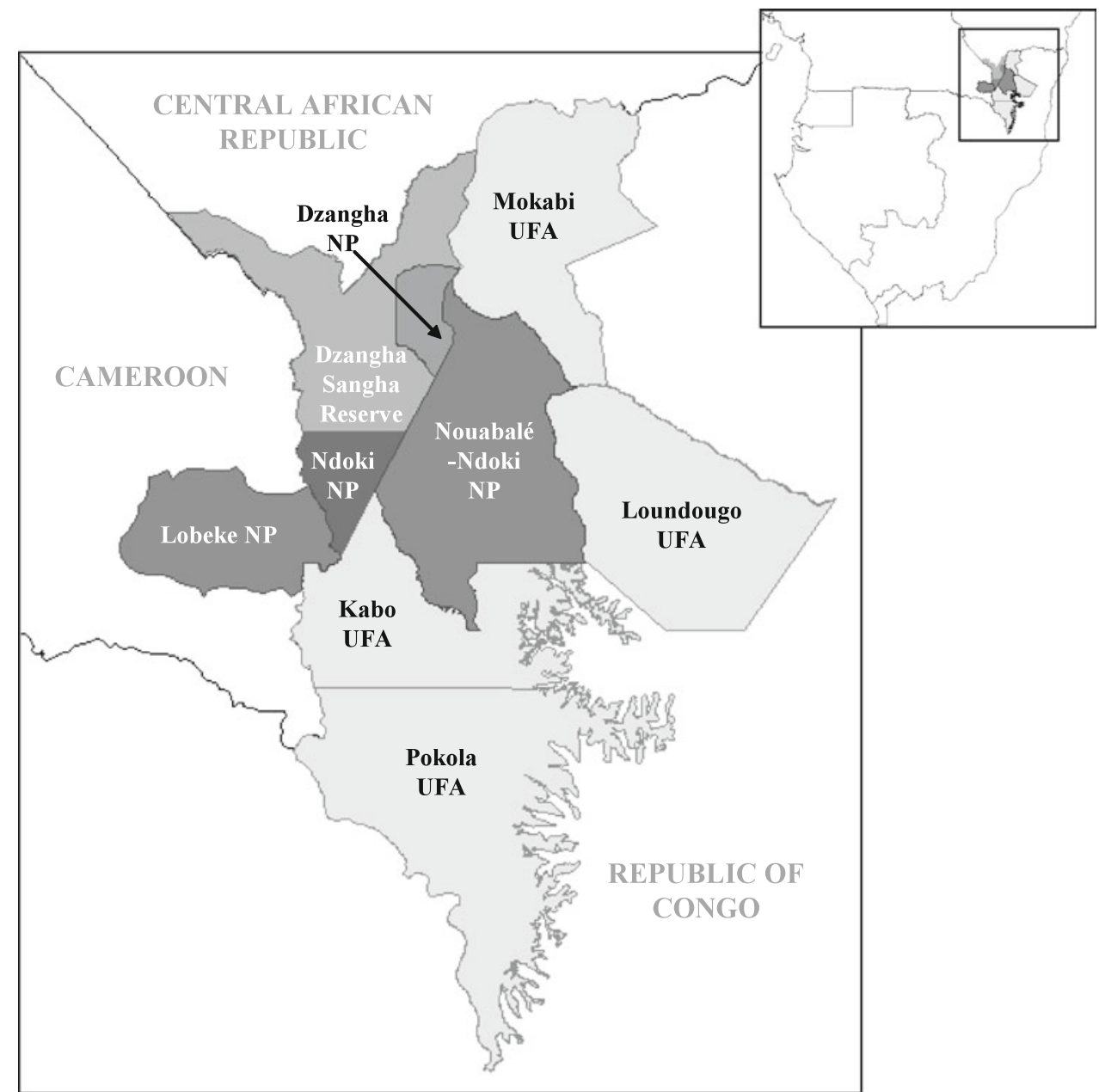

Figure 1. Land use in the Sangha Tri-National Conservation Area at the boundary of Republic of Congo, Cameroon, and the Central African Republic. The Goualougo Triangle is located in the southern portion of the NouabaléNdoki National Park. The Kabo Logging Concession is contiguous to the national park's southern boundary.

announced that it would annex the majority of the Goualougo Triangle to the Nouabalé-Ndoki National Park $\left(4400 \mathrm{~km}^{2}, 2.05^{\prime}-3.03^{\prime} \mathrm{N}, 16.51^{\prime}-16.56^{\prime} \mathrm{E}\right)$. However, the adjacent forest remains in an active logging concession. As part of the Goualougo Triangle Ape Project's mandate to evaluate the impacts of logging on wild apes, this area was stratified into study zones $\left(A, B_{1}, B_{2}, C\right.$, and $\left.D\right)$ with relation to the national park boundaries and logging activities (Fig. 2). Zones $\mathrm{A}_{2} \mathrm{~B}_{1}$, and $\mathrm{B}_{2}$ are undisturbed forest within the national park. Zone $\mathrm{D}$ was logged in the early 1970s, and zone C is slated for logging in the near future. All study zones are characterized by similar terra firma forest dominated by mixed species interspersed with monodominant Gilbertiodendron dewevrei, seasonally flooded forest, and open swamp forests (Morgan et al., 2006).

\section{Sample Collection and Analysis}

Between 2004 and 2009, we conducted repeated reconnaissance and line transect surveys for ape signs in zone D of the Kabo Logging Concession and zones $\mathrm{A}$ and $\mathrm{B}_{1}$ within the Goualougo Triangle (Morgan et al., 2006, 2009). Our first surveys of zone D were conducted after forestry activities had been dormant for more than 30 years. Ape fecal samples were collected opportunistically in the field and preserved in $10 \%$ neutral buffered formalin (Gillespie, 2006). Fecal samples were characterized as chimpanzee or gorilla based on morphological features. At similar sites using similar methods, samples characterized in this fashion were verified to the correct species more than $94 \%$ of the time by genetic methods, with field researchers able to correctly identify gorilla dung $(318 / 324=98 \%)$ more often than chimpanzee fecal remains $(200 / 211=94 \%)$ (Arandjelovic, 2009, personal communication). When collected, fecal material was characterized as soft or firm depending on the consistency, assuming that sick apes will evacuate soft stools (Gillespie et al., 2008). A Merifluor Cryptosporidium/ Giardia Direct Immunofluorescent Detection Kit (Meridian Bioscience, Inc., Cincinnati, $\mathrm{OH}$ ) was used to detect both parasites (Johnston et al., 2003). Fecal samples 

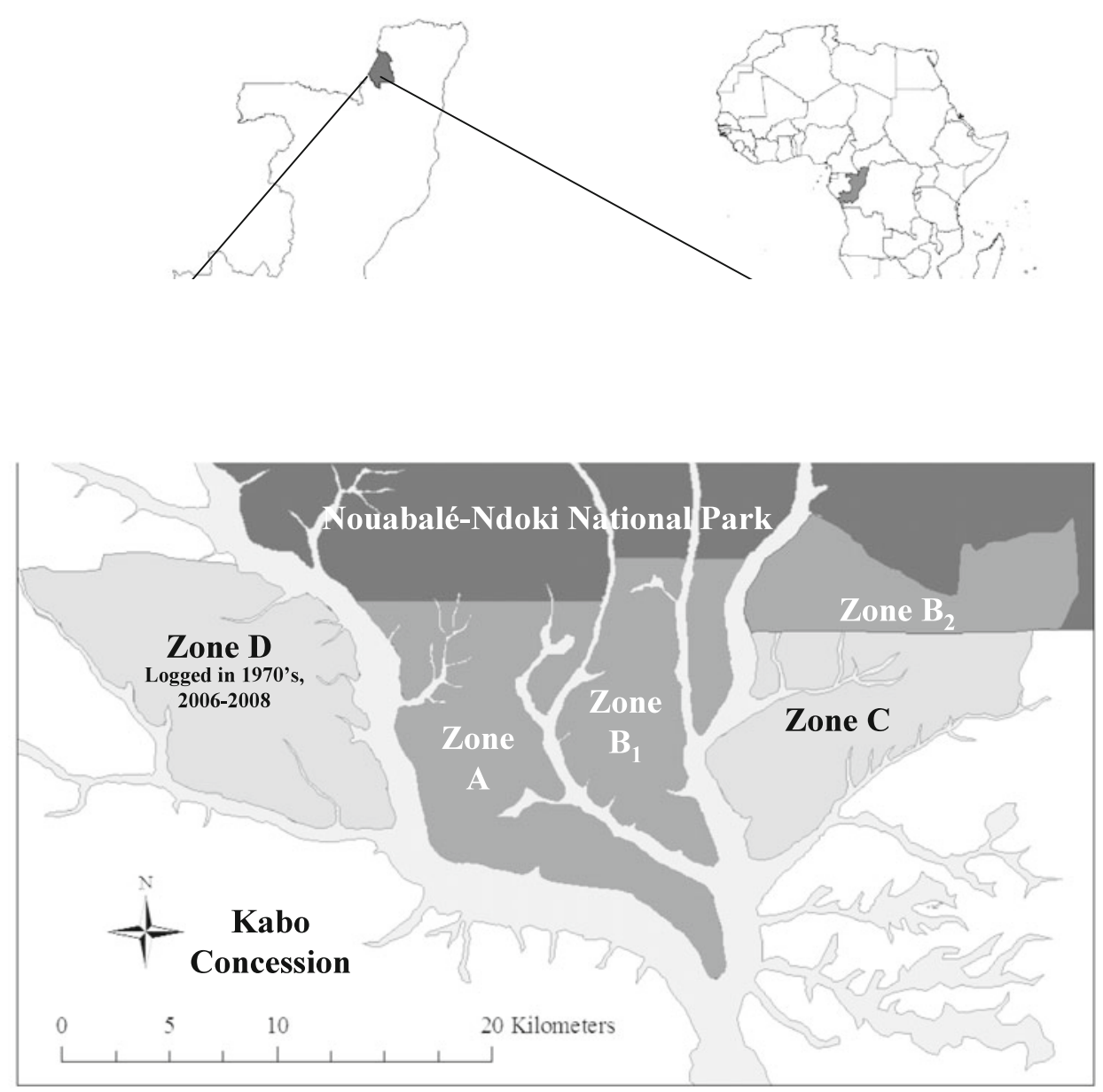

Figure 2. Location of study zones within the Goualougo Triangle (A, $\mathrm{B}_{1}$, and $\mathrm{B}_{2}$ ) and adjacent logging concession (C and D) in Republic of Congo. were scored both for presence or absence of the pathogens as well as quantification of Cryptosporidium sp. oocysts and Giardia sp. cysts in feces. Fecal samples were concentrated and then resuspended in $1 \mathrm{~g} / 1 \mathrm{ml}$ suspensions. Counts were calculated by analyzing $10 \mu \mathrm{l}$ of the $1 \mathrm{~g} / \mathrm{ml}$ solution of concentrated feces from each sample. Oocysts or cysts were then quantified by counting total numbers in 150 microscope fields $(400 \times$ magnification) and extrapolating results to the entire sample. This method was validated by spiking negative fecal samples with known numbers of Cryptosporidium sp oocysts and Giardia sp. cysts. Results were analyzed using EpiInfo, Version 3.3.2 (Centers for Disease Control, Atlanta, GA). A power analysis was conducted using the Finite Population Correction for Proportions (Israel 1992). The corrected sample sizes are calculated using the original sample size results calculated using the equation for a large population. These numbers are based on a confidence level of $95 \%$ and level of precision of 0.05 .

\section{Results}

All 134 samples were negative for Cryptosporidium sp. (Table 1). Three of 34 chimpanzee samples $(8.82 \%)$ from the logged site, 1 of 33 chimpanzee samples from the undisturbed site (3.03\%), 0 of 31 gorilla samples from the logged site $(0 \%)$, and 1 of 36 gorilla samples from the undisturbed sites $(2.78 \%)$ were infected with Giardia sp. (Table 1). Prevalence of infection with Giardia sp. was not significantly different between logged and undisturbed forest for chimpanzees $\left(\chi^{2}=1.00, P=0.32\right.$, degrees of freedom $(d f)=1)$ or gorillas $\left(\chi^{2}=0.87, P=0.35, d f=1\right)$.

Of all 67 chimpanzee samples, one was characterized as soft $(1.5 \%)$ and the remainder as firm $(98.5 \%)$. Of all 67 gorilla samples, 3 were characterized as soft $(4.5 \%)$ and the remainder as firm (95.5\%). There was no relationship between fecal consistency and Giardia infection status for chimpanzees $\left(\chi^{2}=0.00, \quad P=0.78, d f=1\right)$ or gorillas $\left(\chi^{2}=0.07, P=0.78, d f=1\right)$. 
Table 1. Prevalence and intensity of Cryptosporidium and Giardia spp. in chimpanzees and gorillas in the Goualougo Triangle of Nouabalé-Ndoki National Park and Kabo Logging Concession, Republic of Congo

\begin{tabular}{|c|c|c|c|c|c|c|}
\hline \multirow[t]{2}{*}{ Species } & \multirow[t]{2}{*}{ Population } & \multirow[t]{2}{*}{ Samples } & \multicolumn{2}{|l|}{ Cryptosporidium } & \multicolumn{2}{|l|}{ Giardia } \\
\hline & & & Prevalence (\%) & Mean intensity & Prevalence (\%) & Mean intensity \\
\hline \multirow[t]{2}{*}{ Chimpanzee } & Goualougo & 33 & 0 & 0 & 3.03 & 1000 \\
\hline & Kabo & 34 & 0 & 0 & 8.82 & $1833 \pm 573.49$ \\
\hline \multirow[t]{2}{*}{ Gorilla } & Goualougo & 36 & 0 & 0 & 9.78 & 900 \\
\hline & Kabo & 31 & 0 & 0 & 0 & 0 \\
\hline
\end{tabular}

Mean intensities are expressed as oocysts (Cryptosporidium) or cysts (Giardia) per gram, standard error of the mean; negative samples are not included in this calculation.

Our power analysis demonstrated that additional zone D chimpanzee sampling would be required to ensure that the lack of significance observed in intersite comparisons of chimpanzees Giardia sp. prevalence is indeed valid (47 zone D compared with the 34 collected thus far). Samples were collected during repeated line transect surveys during a period of 5 years. Collection of fresh ape feces in this system requires a tremendous amount of effort. Three to five samples can be collected in a day by a team of five trackers. Samples are collected by backtracking sighted apes to find feces voided within the past hour. Aged feces, such as those from night nests are not collected. Due to these limitations, we regard the lack of significant differences in Giardia sp. prevalence between sites for chimpanzees to be preliminary. Additional sampling will be required to definitively examine this comparison.

We also compared the intensity of infection for each ape species between logged and undisturbed sites. The mean intensity of infection was highest in chimpanzees from the disturbed site $(1833 \pm 573.49$ cysts/g), followed by chimpanzees in the undisturbed site (1000 cysts/g). Mean intensity of infection was slightly lower for gorillas from the undisturbed site (900 cysts/g), and no infections were found in gorillas from the disturbed site, resulting in an intensity of zero (Table 1); mean intensities of infection could not be compared statistically across sites due to rarity of infection.

\section{DIsCUSSION}

Our results demonstrate that Giardia sp. is present at low prevalence in chimpanzees and lowland gorillas in undisturbed forests and forests with a history of selective logging. In these same populations, there is no evidence of infection with Cryptosporidium sp. A lack of Cryptosporidium sp. in all samples examined suggests that Cryptosporidium sp. is not a natural component of ape parasite communities at this site and that historical land-use patterns are not exposing apes to zoonotic sources of this pathogen. Low prevalence of Giardia sp. in the study area regardless of historical land-use patterns suggest that a low level of circulating Giardia is a natural component of Congolese ape parasite communities and that historical land-use patterns are not exposing apes to zoonotic sources of this pathogen. Our study area is located only $32 \mathrm{~km}$ from the nearest village and the large river that serves as a major transportation source for the region. However, the forest is continuous and the encounter rate of human signs in the study zones was low, which confirms that these forests have remained relatively undisturbed despite past timber exploitation. This post-logging scenario is much different than the high human densities and forest fragmentation typical in east and west Africa.

Giardia and Cryptosporidium are notable for cross-species transmission (Thompson, 2004). The propensity of these protozoans to cross species barriers results from the host nonspecificity of trophozoites of either genus, and the high infectivity and environmental stability of Giardia cyst and Cryptosporidium oocysts (Smith and Nichols, 2006). Previous field-based studies confirm this pattern, demonstrating that high levels of primate-human overlap enhance transmission of potentially pathogenic protozoa, including Giardia sp. and Cryptosporidium sp. (Nizeyi et al., 2002; Graczyk et al., 2001a, b; Graczyk et al., 2002; Salzer et al., 2007). The results of the current study are the first to examine the long-term effects of historical primate-human overlap on contemporary patterns of infection with these pathogens.

Considered among the most common human intestinal protozoa, Giardia ranges in clinical presentation from 
asymptomatic to highly pathogenic, causing chronic malabsorptive diarrhea in some patients (Thompson, 2004). Both host factors (e.g., nutrition, immunity, coinfection with other agents) and pathogen factors (e.g., strain, infectious dose) are thought to contribute to the severity of clinical disease (Thompson, 2000). Giardiasis is now considered by the World Health Organization to be a "neglected disease," due to its ubiquity in equatorial latitudes, its chronic detrimental health effects (especially in children), its propensity to infect economically disadvantaged populations, and the paradoxical availability of relatively inexpensive and effective pharmaceuticals for its treatment (Savioli et al., 2006).

In our study, we found no relationship between infection status and fecal consistency (soft vs. firm). The lack of a strong measurable association between infection and acute gastrointestinal symptoms in our study population was surprising, but it is concordant with recent studies of humans. Although Giardia is associated with clinical diseases in developed economies, evidence is nevertheless mounting that it may be commensal in rural settings where people may normally be exposed to diverse parasite communities from an early age. For example, Peréz Cordón et al. (2008) found Giardia at $28.1 \%$ prevalence in diarrheic Peruvian children, as well as in $19.5 \%$ of nondiarrheic children, emphasizing the importance of asymptomatic patients in Giardia transmission where hygiene and sanitation are poor (Peréz Cordón et al., 2008). Other studies in India (Traub et al., 2003), Ethiopia (Ayalew et al., 2008), Bangladesh (Dib et al., 2008), and Peru (Hollm-Delgado et al., 2008) have found similarly weak or nonexistent associations between $G$. duodenalis infection status and gastrointestinal symptoms, suggesting that $G$. duodenalis may coexist benignly with human hosts under conditions where acquired immunity to the pathogen can develop. Lack of early exposure and acquired immunity to G. duodenalis may, in fact, account for the role of the pathogen as a cause of sporadic diarrheal outbreaks in developed countries (Istre et al., 1984), as well as a major cause of traveler's diarrhea for people from developed countries who visit endemic areas (Reinthaler et al., 1998; Shlim et al., 1999). The interplay between clinical symptoms and Giardia infections in wildlife are far less known. We hope to explore in detail the association between symptom and infection in apes in more detail in future work.

Our results from the Goualougo Triangle provide a rare opportunity to observe baseline patterns of infection in undisturbed ape populations. Baseline patterns of parasitism are necessary to understand both individual animal health status and to assess what would constitute an "outbreak": a level of disease or parasitism in excess of what is normally observed. Thus, these results provide a first step toward an index of population health and disease risk assessment for conservation and management plans of these endangered African ape populations.

Our results from the Kabo Concession suggest that a legacy of low-intensity selective logging did not result in the persistence of elevated prevalence of Cryptosporidium $s p$. and Giardia sp. in these ape populations. It is encouraging that the resident ape populations are not suffering from infections of these protozoa, because this suggests such potential health threats may be mitigated. However, if these protozoa are exceptionally pathogenic in wild ape populations, infected individuals may have been removed from the population long ago due to high associated mortality.

We have yet to examine how patterns and risk of parasitism may differ during the various stages of the active logging process (i.e., exploration, road construction, and timber harvesting) from those that are the product of a legacy of selective logging. The expansion of timber activities in the neighboring undisturbed forests of the Kabo concession will enable us to address these questions through an ongoing progressive monitoring program that involves documenting ape populations, human disturbance, and the health implications during their interactions.

\section{ACKNOWLEDGMENTS}

Permission and logistical support for this research was provided by the Government of the Republic of Congo and the Congo Program of the Wildlife Conservation Society. C. Eyana assisted with data collection and a dedicated team of assistants from the villages of Bomassa and Makao provided invaluable assistance in the field. The authors thank N. Hauser and E. Canfield for laboratory assistance and two anonymous reviewers for helpful comments on an earlier draft of this manuscript. Funding for this research was provided the National Institutes of Health (NIH Grant T35 2006), the U.S. Fish and Wildlife Service (Great Ape Conservation Fund), and the National Geographic Society.

\section{REFERENCES}

Appelbee AJ, Thompson RCA, Olson ME (2005) Giardia and Cryptosporidium in mammalian wildlife - current status and future needs. Trends in Parasitology 21:370-376 
Auzel P, Wilkie D (2000) Wildlife use in northern Congo: hunting in a commercial logging concession. In: Hunting for Sustainability in Tropical Forests, Robinson J, Bennett E (editors), New York: Columbia University Press, pp 413-426

Ayalew D, Boelee E, Endeshaw T, Petros B (2008) Cryptosporidium and Giardia infection and drinking water sources among children in Lege Dini, Ethiopia. Tropical Medicine and International Health 13(4):472-475

Barnes RFW, Lahm SA (1997) An ecological perspective on human densities in central African forests. Journal of Applied Ecology 34:245-260

Beldomenico PM, Telfer S, Gebert S, Lukomski L, Bennett M, Begon M (2008) Poor condition and infection: a vicious circle in natural populations. Proceedings of the Royal Society $B$ 275:1753-1759

Boardman H, Isik G, Plaza S, Ye X, Yoshino Y (2007) Africa's Silk Road: China and India's New Economic Frontier, Washington DC: The World Bank

Chapman CA, Balcomb SR, Gillespie TR, Skorupa JP, Struhsaker TT (2000) Long-term effects of logging on primates in Kibale National Park, Uganda: a 28-year comparison. Conservation Biology 14:207-217

Clark CJ, Poulsen JR, Malonga R, Elkan PW (2009) Logging concessions can extend the conservation estate for Central African tropical forests. Conservation Biology 23:1281-1293

Dib HH, Lu SQ, Wen SF (2008) Prevalence of Giardia lamblia with or without diarrhea in South East, South East Asia and the Far East. Parasitology Research 103:239-251

Eves HE, Ruggiero RG (2000) Socioeconomics and sustainability of hunting in the forests of northern Congo (Brazzavile). In: Hunting for Sustainability in Tropical Forests, Robinson JG, Bennett L (editors), New York: Columbia University Press, pp 427-454

Frumhoff PC (1995) Conserving wildlife in tropical forests managed for timber. BioScience 45:456-464

Gillespie TR (2006) Non-invasive assessment of gastro-intestinal parasite infections in free-ranging primates. International Journal of Primatology 27:1129-1143

Gillespie TR, Chapman CA, Greiner EC (2005) Effects of logging on gastrointestinal parasite infections and infection risk in African primates. Journal of Applied Ecology 42:699-707

Gillespie TR, Nunn CL, Leendertz F (2008) Integrative approaches to the study of primate infectious disease: implications for biodiversity conservation and global health. Yearbook of Physical Anthropology 51:53-69

Graczyk TK, DaSilva AJ, Cranfield MR, Bosco Nizeyi J, Kalema GRNN, Pieniazek NJ (2001) Cryptosporidium parvum Genotype 2 infections in free-ranging mountain gorillas (Gorilla gorilla beringei) of the Bwindi Impenetrable National Park, Uganda. Parasitology Research 87(5):368-370

Graczyk TK, Marcogliese DJ, deLafontaine Y, DaSilva AJ, Mhangami-Ruwende, Pieniazek NJ (2001) Cryptosporidium parvum oocysts in zebra mussels (Dreissena polymorpha): evidence from the St. Lawrence River. Parasitology Research 87(3):231-234

Graczyk TK, Bosco-Nizeyi J, Ssebide B, Thompson RC, Read C, Cranfield MR (2002) Anthropozoonotic Giardia duodenalis genotype (assemblage) a infections in habitats of free-ranging human-habituated gorillas, Uganda. Journal of Parasitology 88:905-909

Hall SH, Harris DJ, Medjibe V, Ashton MS (2003) The effects of selective logging on forest structure and tree species composition in a Central African forest: implications for management and conservation. Forest Ecology and Management 183: 249-264

Heydon MJ, Bulloh P (1997) Mouse deer densities in a tropical rainforest: the impact of selective logging. Journal of Applied Ecology 34:484-496

Hollm-Delgado MG, Gilman RH, Bern C, Cabrera L, Sterling CR, Black RE, Checkley W (2008) Lack of an adverse effect of Giardia intestinalis infection on the health of Peruvian children. American Journal of Epidemiology 168:647-655

Hudson PJ, Rizzoli A, Grenfell BT, Heesterbeek H, Dobson AP (2001) Ecology of Wildlife Diseases, Oxford: Oxford University Press

Istre GR, Dunlop TS, Gaspard GB, Hopkins RS (1984) Waterborne giardiasis at a mountain resort: evidence for acquired immunity. American Journal of Public Health 74:602-604

Johnston SP, Ballard MM, Beach MJ, Causer L, Wilkins PP (2003) Evaluation of three commercial assays for detection of Giardia and Cryptosporidium organisms in fecal specimens. Journal of Clinical Microbiology 41(2):623-626

Matthews A (2004) Survey of gorillas (Gorilla gorilla gorilla) and chimpanzees (Pan troglodytes troglodytes) in Southwestern Cameroon. Primates 45:15-24

Morgan D, Sanz C, Onononga JR, Strindberg S (2006) Ape abundance and habitat use in the Goualougo Triangle, Republic of Congo. International Journal of Primatology 27:147-179

Morgan D, Sanz C, Onononga JR, Stokes E, Lonsdorf E, Strindberg S (2009) The effects of logging practices on great apes in the Ndoki Forests, Republic of Congo. PLOS One (in press)

Nizeyi JB, Sebunya D, Da Silva AJ, Cranfield MR, Pieniazek NJ, Graczyk TK (2002) Cryptosporidiosis in people sharing habitats with free-ranging mountain gorillas (Gorilla gorilla beringei), Uganda. American Journal of Tropical Medicine and Hygiene 66:442-444

Nunn CL, Altizer S, Jones KE, Sechrest W (2003) Comparative tests of parasite species richness in primates. American Naturalist 62:597-614

Olupot W, Chapman CA, Brown CH, Waser PM (1994) Mangabey (Cercocebus albigena) population density, group size and ranging: a twenty-year comparison. American Journal of Primatology 32:197-205

Patriquin KJ, Barclay RMR (2003) Foraging by bats in cleared, thinned and unharvested boreal forest. Journal of Applied Ecology 40:646-657

Peréz Cordón G, Cordova Paz Soldan O, Vargas Vásquez F, Velasco Soto JR, Sempere Bordes LI, Sánchez Moreno M, Rosales MJ (2008) Prevalence of enteroparasites and genotyping of Giardia lamblia in Peruvian children. Parasitology Research 103(2):459-465

Reinthaler FF, Feierl G, Stunzner D, Marth E (1998) Diarrhea in returning Austrian tourists: epidemiology, etiology, and costanalyses. Journal of Travel Medicine 5:65-72

Salzer JS, Rwego IB, Goldberg TL, Kuhlenschmidt MS, Gillespie TR (2007) Giardia sp. infections in primates in fragmented and undisturbed forest in western Uganda. Journal of Parasitology 93:439-440

Savioli L, Smith H, Thompson A (2006) Giardia and Cryptosporidium join the 'Neglected Diseases Initiative'. Trends in Parasitology 22:203-208

Shlim DR, Hoge CW, Rajah R, Scott RM, Pandy P, Echeverria P (1999) Persistent high risk of diarrhea among foreigners in 
Nepal during the first 2 years of residence. Clinical Infectious Diseases 29:613-616

Skorupa JP (1987) Do line-transect surveys systematically underestimate primate densities in logged forests? American Journal of Primatology 13:1-9

Smith H, Nichols RA (2006) Zoonotic protozoa - food for thought. Parasitologia 48:101-104

Struhsaker TT (1997) Ecology of an African Rain Forest: Logging in Kibale and the Conflict between Conservation and Exploitation, Gainsville: University Press of Florida

Thompson RC (2000) Giardiasis as a re-emerging infectious disease and its zoonotic potential. International Journal of Parasitology 30:1259-1267

Thompson RCA (2004) Epidemiology and zoonotic potential of Giardia infections. In: World Class Parasites, Vol 8: The Pathogenic Enteric Protozoa: Giardia, Entamoeba, Cryptosporidium and Cyclospora, Sterling CR, Adam RD (editors), Boston: Kluwer Academic Publishers, pp 1-14

Traub RJ, Robertson ID, Irwin P, Mencke N, Monis P, Thompson RC (2003) Humans, dogs and parasitic zoonoses: unravelling the relationships in a remote endemic community in northeast India using molecular tools. Parasitology Research 90(3):156157

Van Gemerden BS (2003) The pristine rainforest: remnants of historical human impacts on current tree species composition and diversity. Journal of Biogeography 30(9):1381-1390

White LJT (1992) Vegetation history and logging disturbance: effects on rain forest mammals in the Lope Reserve, Gabon. $\mathrm{PhD}$ thesis.

White LJT, Tutin CEG (2001) Why chimpanzees and gorillas respond differently to logging: a cautionary tale from Gabon. In: African Rain Forest Ecology and Conservation, Weber B, White LJT, Vedder A, Simons-Morland H (editors), New Haven: Yale University Press

Wilkie DS, Carpenter JF (1998) Managing bush meat hunting in the Congo Basin: an assessment of the impacts and question for mitigation. Biodiversity and Conservation 8:927-955 